\title{
PASTORAČNÉ AKTIVITY A SOCIÁLNA ZMENA RÓMOV
}

\author{
Viktor Tomčányi - Rastislav Rosinský \\ Ústav romologických štúdií FSVaZ UKF Nitra \\ zioviki@gmail.com, rrosinsky@ukf.sk
}

\begin{abstract}
Abstrakt:
Východiská: Viaceré domáce a zahraničné skúsenosti potvrdzujú fakt, že dôsledná pastoračná aktivita s chudobnými Rómami je schopná vyvolat' reakciu v podobe sociálnej zmeny.

Ciel': Ciel'om bolo zmapovat' najúčinnejšie metódy pastoračných aktivít, ktoré dokážu vyvolat' sociálnu zmenu a zistit', aké výsledky prináša pastoračná aktivita na niektoré skupiny Rómov v nepriaznivej sociálnej situácii.

Metódy: Metódou pološtruktúrovaného rozhovoru s 27 duchovnými z registrovaných cirkví vSR pôsobiacimi v Nitrianskej diecéze sme výsledky analyzovali metódou vytvárania trsov. Kritériom výberu zo základného súboru boli vopred dohl'adané informácie o pastoračných aktivitách duchovných.

Výsledky: Z výsledkov vyplýva, že duchovní sa vo svojej činnosti venujú najmä det'om a mládeži, aj ked' priznávajú, že ak má príst' k zmene, je potrebné pracovat' s rodičmi detí. S chudobnými Rómami sa stretávajú vo väčšine prípadov iba v škole, prípadne pri bežnom kontakte v obci. Aj ked' priznávajú, že Rómovia majú záujem o sviatosti, ale najmä o krst a pohreb, čo je pre cirkvi málo. S det'mi realizujú najmä pravidelnú mimoškolskú katechézu, vytvárajú mládežnícke spoločenstvá. Identifikovali sme aj prípady duchovných, ktorí nerobia vôbec žiadnu činnost' vo vzt'ahu k Rómom. Tí ktorí takúto činnost' vykonávajú, medzi najúčinnejšie metódy práce považujú najmä osobný kontakt, ktorý tvorí most k d'alším aktivitám.

Implikácie: Duchovní všetkých cirkví by mali byt' služobníkmi všetkých l'udí. Ak chceme dosiahnut' sociálnu zmenu medzi marginalizovanými skupinami obyvatel'stva je potrebné, aby duchovní vyšli zo svojej zóny konformity a boli bližšie k zranitel'ným l'ud'om. Práca s mládežou ale najmä s celou rodinou dokáže robit' vel'ké zmeny. Práca ale musí byt' pravidelná a najmä osobný kontakt v teréne je to, čo tvorí základ budúcej zmeny. Občasný kontakt len v kostole či na fare nie je účinný.
\end{abstract}

Kl'účové slová: Pastoračná činnost'. Rómovia. Sociálna zmena.

\section{ÚVOD}

Rómske etnikum nežije iba na území Slovenska, ale skoro v každom európskom štáte. 0 tom, ako žijú, nás aktuálne informujú média, ktoré sprostredkúvajú skôr ich negatívne stránky (Analýza, 2014). Rómom pomáhajú viaceré organizácie, ale aj Cirkev. Mnohým z nich, ktorí sa dostali do nepriaznivej sociálnej situácie pomáha Cirkev k sociálnej zmene. Existuje len málo vedeckých štúdií o pastoračných aktivitách cirkví, ktoré vedú k sociálnej zmene u Rómov žijúcich $\mathrm{v}$ nepriaznivej sociálnej situácii. Skôr sú to „životné vedecké štúdie“, ktoré napísal samotný život jednotlivých duchovných a komunít roztrúsených po celom svete. Oni zasvätili svoj život rómskemu národu. Mnohí s nimi aj žijú, slúžia im a pomáhajú im k sociálnej zmene.

V Bulharsku, vČeskej republike a v Rumunsku v tejto oblasti úspešne pracujú duchovní zo spoločnosti Dona Bosca (saleziáni). V Bulharsku pracuje komunita saleziánov v krajskom meste 
Staré Zagory, ktoré leží na juhu krajiny. Mesto má 141597 obyvatel’ov, z toho 27000 Rómov. Medzi svoje úspechy zarad'ujú: získanie dôvery rodičov rómskej komunity, pravidelnú školskú dochádzku, väčšie ticho a poriadok pri spoločných programoch, zlepšenie verejnej mienky o Rómoch z pohl'adu majoritnej spoločnosti (Svoboda, 2009). V Českej republike pracujú s obyvatel'mi marginalinazovaných komunít aj $\mathrm{v}$ Ostrave, kde je aj najväčšia koncentrácia chudobných, Rómov (aj bezdomovcov) vČR. V pastoračnej oblasti sa venujú pravidelnej skupinovej katechéze a sv. omšiam, realizujú duchovný program na pobytových akciách, pripravujú deti a ich rodičov k sviatostiam (Kuchař, 2009). VRumunsku podl'a posledného štatistického sčítania obyvatel'stva žije 535250 Rómov, čo predstavuje 2,5 \% z celkového počtu obyvatel'stva. Tak ako aj inde, pastoračné aktivity majú malé aj väčšie úspechy. Treba si však všimnút', že vnútri tradičných cirkví existujú prorocké gestá: osoby, hnutia a združenia rozvíjajúce nádejné znamenia obnovy pastorácie Rómov (Lucian, 2015). V Taliansku sa náboženský život stále rozvíja. Koná sa tu množstvo aktivít. Pribúdajú mnohé centrá, ktoré napomáhajú duchovnému rastu. Mladá generácia Rómov na niektorých miestach preberá zodpovednost' za osud a budúcnost' rómskeho národa. Rómka Eva Rizzin v roku 2007 pôsobila aj v Európskom parlamente (Messaggero, 2007). Existujú aj rómske duchovné povolania (kňazi, diakoni, rehol'né sestry a mnohí katechéti). Každoročne sa uskutočňujú mnohé rómske púte (Adami a Martír, 2014). V Španielsku sa chvália úspechmi v centrách pre Rómov. Deti, ktoré prešli centrom sú dnes už rodičmi a sami doň prinášajú svoje deti, pretože v ňom prežili najšt'astnejšie chvíle svojho života. Mnohí z mladých, ktorí prešli centrom vedú dnes dôstojný život a vyhli sa väzeniu a drogám. Iní l'udia zas nachádzajú v týchto priestoroch výchovné motívy a spôsoby, ako čelit' t’ažkostiam života (Vergara, 2009). V Mad'arsku nám hodnotné výsledky priniesla vedecká práca Olaha Dezsö. Vo svojej štúdii prezentoval sociálne zmeny, ktoré nastali v každodennom živote Rómov po pastoračných aktivitách duchovných. Sú to najmä: nový zmysel života, usporiadanie manželstva, väčšia tolerancia voči druhým a začlenenie sa do novej komunity. Autor tvrdí, že Cirkev môže Rómom pomôct', aby sa svojím obrátením a sociálnou zmenou plnohodnotne začlenili do majoritnej spoločnosti (Rómské rodiny, 2015). Na Slovensku by sme mohli čerpat' z vedeckej práce Petra Besenyiho (2011), ktorý tvrdí, že proces socializácie a následnej integrácie Rómov by mal byt' zavŕšený sociálnou inklúziou, ktorú iniciuje a koriguje misijná činnost' (duchovná obroda), sociálna práca (komunitná práca a terénna sociálna práca) a vzdelávanie s následným zamestnaním sa. Všetky tieto smery by mali byt' aktívne a racionálne (koncepčne) podporované štátnou sociálnou politikou. Sú to účinné nástroje prispievajúce k sociálnej inklúzii marginalizovanej rómskej menšiny do majoritnej spoločnosti.

Do našej pozitívnej mozaiky týkajúcej sa vplyvu pastorácie na sociálnu zmenu obyvatel’ov marginalizovaných komunít zapadá aj zistenie projektu SIRONA, ktorý bol realizovaný Ústavom etnológie SAV (2010). Autori tohto výskumu hovoria o svojom kl'účovom zistení a tvrdia: „Výskum zistil, že pri náboženskej zmene dochádza aj k sociálnej zmene: t. j. k širokospektrálnej zmene sociálnych návykov a správania sa jednotlivcov, respektíve určitej skupiny. Výskum SIRONA 2010 tiež ukázal, že z hl'adiska stability tejto zmeny je ideálne, ak prebieha na komunitnej/kolektívnej úrovni.“" (Podolinská, Hrustič, 2010, s.11).

\section{Pastoračná aktivita a sociálna zmena}

Pastoračnú aktivitu by sme mohli zadefinovat' aj ako službu lásky človeku vo všetkých dimenziách jeho života. Nemá to byt' jednorazová pomoc, ale celoživotná, nezištná misia, starostlivost' o každého človeka. Podl'a pápeža Františka (2013) je misia krest’ana vo svete úžasná, je to misia určená všetkým, je to misia služby bez výnimky. Pastoračná aktivita je sprevádzanie človeka od jeho počatia až po prirodzenú smrt' (Giovanni XXIII., 2007). Cirkev sa od svojho ustanovenia snaží slúžit' l'udskej rodine, je kreatívna v prostriedkoch a spôsoboch ako sa 
dotknút' l'udského srdca a formovat' ho tak, aby sa u neho dosiahla aj sociálna zmena. Je to pastoračná láska, ktorá sa snaží vždy chciet' len dobro pre konkrétnu osobu. Vie, že táto osoba sa zvyčajne rodí v rodine, kde všetko začína. Podl'a Holmena (2005) Cirkev zvlášt' dnes zameriava svoju pozornost' na rodinu, ked'že v nej je začiatok všetkého dobra i zla.

„Zmena je trvalou charakteristikou spoločného života. Vo všeobecnosti ju možno charakterizovat’ ako „nadobúdanie iných charakteristík, premenu štruktúry alebo situácie v čase“ (Košta, 1993, s. 104). „Za sociálne zmeny sa pokladajú predovšetkým zmeny v oblasti kultúry spoločnosti, zmeny jej sociálnej štruktúry, sociálneho správania l'udí, zmeny vzt’ahov medzi jednotlivcami, sociálnymi skupinami a podobne" (Miedzgová, 1996, s. 77). Sociálne zmeny prebiehajú rôznymi spôsobmi, na rôznych úrovniach a v rôznych oblastiach života spoločnosti a jednotlivcov. Spôsobujú ich rôzne skutočnosti, majú rôzne výsledky atd'. Sociálna zmena môže prebiehat' rôznym tempom, môže mat' rôznu dížku trvania a môže dosiahnut' rôzny rozsah a vel'kost'. „Sociálne zmeny sa odohrávajú v rôznych oblastiach života spoločnosti. Môžu sa odohrávat’ v rodine, u jednotlivca, v rámci populácie, v rámci sociálnej stratifikácie, vekonomike a v d’alších oblastiach spoločenského života." (Sopóci, 2007, s. 12). Za zdroje sociálnej zmeny sa pokladajú príčiny, impulzy, faktory, ktoré vyvolávajú jej vznik a podporujú jej priebeh a trvanie. Medzi faktory sociálnej zmeny patria podl'a Montoussa a Renouarda (2005, s. 95) „aj náboženské hodnoty“.

\section{METÓDY}

Ako vidiet’ z predchádzajúcich častí, zameranie nášho výskumu smeruje k základnej výskumnej otázke: Aké pastoračné aktivity považujú duchovní za najúčinnejšie k dosiahnutiu sociálnej zmeny u niektorých skupín Rómov? V kvalitatívnej časti nášho výskumu bola použitá metóda pološtrukturovaného rozhovoru. Chceli sme sa dozvediet', aké výsledky prináša pastoračná činnost' duchovných, ktorí sa jej prostredníctvom snažia vplývat' na sociálnu zmenu niektorých Rómov v nepriaznivej sociálne situácii. Vzájomný dialóg sme rozvíjali na základe otázok, ktoré sme si vopred pripravili. Trval od 10 do 40 minút. Rozhovory prebiehali v prirodzenom prostredí respondentov.

Získané údaje sme spracovali metódou vytvárania trsov. Táto metóda slúži obvykle k tomu, aby sme zoskupili a konceptualizovali získané výsledky do skupín na základe diferenciácie určitých javov, miesta, prípadu. Tieto skupiny (trsy) by mali vznikat' na základe vzájomných premís medzi identifikovanými jednotkami. Týmto procesom vznikajú všeobecné, indukovane sformované kategórie. Ich zaradenie do danej skupiny (trsov) je asociované s určitými opakujúcimi sa charakteristikami, znakmi. Spoločným znakom takéhoto trsu je tematické prekrývanie sa (Miovský, 2006).

\section{Výskumná vzorka}

Kritériom na zaradenie do základného súboru bola profesijná príslušnost' k registrovaným cirkvám v jednej z diecéz v Slovenskej republiky. Kritériom výberu zo základného súboru pre realizáciu rozhovorov boli informácie o ich pastoračných aktivitách. Vyžadovali sme, aby duchovní realizovali isté aktivity, pri ktorých sme predpokladali, že budú pozitívne vplývat' na sociálnu zmenu u marginalizovaných Rómov. Celkovo naša vzorka obsahuje 27 respondentov.

\section{VÝSLEDKY}

Pre lepšie pochopenie vplyvu pastoračnej činnosti duchovných na sociálnu zmenu niektorých Rómov, ktorí sa dostali do zlej sociálnej situácie, sme si stanovili kategorické oblasti skúmania. V našom článku sa budeme venovat' prvej kategorickej oblasti, v ktorej popíšeme najúčinnejšie 
pastoračné aktivity duchovných, ktoré pomohli Rómom k sociálnej zmene. Primárne sme sa zamerali na duchovných, s ktorými sme robili osobný rozhovor. Orientovali sme sa na tie pastoračne aktivity, ktoré sa realizujú s Rómami žijúcimi na území farnosti. Zároveň sme reflektovali aj názory duchovných na to, aký prístup majú Rómovia k ponúkaným aktivitám.

Použitím metódy rozhovoru sme sa zamerali na pastoračné aktivity duchovných vo svojich farnostiach, ktoré realizovali pri Rómoch. Zamerali sme sa predovšetkým na hodnotenie významu takých aktivít, ktoré bezpečne viedli k sociálnej zmene.

\section{- skupiny Rómov, ktorým sa duchovní venujú}

Tab. 1 Ciel’ové skupiny, ktorým sa duchovní venujú

\begin{tabular}{|l|l|}
\hline Indukované kategórie & Akej generačnej skupine sa venujete? \\
\hline \multirow{2}{*}{ Deti } & $\begin{array}{l}\text { "V misijnom dome mávame pravidelné stretnutia, počas ktorých } \\
\text { formujeme hlavne deti." Rímskokatolícka cirkev, 28. ročný „Hlavne } \\
\text { v škole sa snažíme najviac oslovit” deti, mat” o nich záujem ako } \\
\text { o človeka." (RKC, 30). }\end{array}$ \\
\hline Mládež & $\begin{array}{l}\text { "S dospievajúcimi sa najviac stretávam v škole." (RKC, 30). } \\
\text { "Do komunitného centra rada a pravidelne chodieva mládež." (RKC, }\end{array}$ \\
\hline Rodičia & $\begin{array}{l}\text { "S rodičmi sa stretávam pred 1. svätým prijímaním." (RKC, 44). } \\
\text { "Po bohoslužbách sa venujem rodičom.“ Reformovaná krest'anská } \\
\text { cirkev, 45. ročný. } \\
\text { "Kontakt s rodičmi je nevyhnutný, pretože aj rodičia potrebujú pomoc, } \\
\text { aby aj oni dozrievali k zodpovednému rodičovstvu, a tak sa stali } \\
\text { pozitívnym príkladom pre svoje deti.“ (RKC, 49). }\end{array}$ \\
\hline
\end{tabular}

Identifikované kategórie: Prostredníctvom tejto otázky sme chceli zistit', akej generačnej, vekovej skupine Rómov sa duchovní venujú. Zistili sme, že najčastejšie sú to deti a mládež, pretože duchovní sa s nimi pravidelne stretávajú vškole na hodinách náboženstva. Potom sú to mimoškolské aktivity, ktoré tiež pomáhajú k ich vzájomnému poznaniu, ktoré je pomocou pri formácii k sociálnej zmene. Niektorí participanti považujú kontakt s rodičmi za nevyhnutný. Uvedomujú si, že ked’ dôjde k sociálnej zmene u rodičov, potom sa l'ahšie dosiahne zmena aj u detí. Tie nie sú motivované len zo strany duchovných, ale hlavne zo strany rodičov, ktorí majú viacej možností a času na dosiahnutie zmeny.

\section{- Intenzita stretávania sa}

Tab. 2 Záujem o kontakt duchovných s marginalizovanými Rómami

\begin{tabular}{|l|l|}
\hline Indukované kategórie & Ako často sa stretávate s Rómami? \\
\hline Pravidelne & $\begin{array}{l}\text { "Môj pravidelný kontakt s Rómami je v škole." ( RKC, 45). } \\
\text { "S det'mi nie sme len v škole, prichádzajú pravidelne aj na detské sv. } \\
\text { omše nás ešte viacej zblí̌ilo." (RKC, 28). } \\
\text { "Pravidelné stretnutia v komunitnom centre nás zblížili s det'mi, } \\
\text { a potom aj s rodinami.“ (RKC, 49). }\end{array}$ \\
\hline
\end{tabular}




\begin{tabular}{|l|l|}
\hline Zriedka & $\begin{array}{l}\text { „S dospelými sa občas stretnem v kostole, ked' prídu pýtat’ svätenú } \\
\text { vodu.“ (RKC, 52). } \\
\text { "Môj kontakt s Rómami je iba na ulici, ked' sa stretneme a vzájomne sa } \\
\text { pozdravíme." (RKC, 45). }\end{array}$ \\
\hline Vôbec & $\begin{array}{l}\text { "Nevenujem sa Rómom, lebo nepoznám rómske etnikum.“ (RKC, 47). } \\
\text { "Rómovia sú pre mňa uzavretá, neprechodná komunita." (RKC, 52). } \\
\text { "Nemám záujem o Rómov odvtedy, čo ma vykradli.“ (RKC, 50). }\end{array}$ \\
\hline
\end{tabular}

Identifikované kategórie: Identifikovali sme tri indukované kategórie, v ktorých sme poukázali na kontakt duchovných s Rómami. Opät' je to predovšetkým prostredie školy, kde sa zvyčajne aspoň jedenkrát do týždňa stretávajú na hodinách náboženskej výchovy. Tam, kde sú duchovní trochu kreatívni, prichádzajú do kontaktu s Rómami na mimoškolských akciách, ako sú detské sväté omše, a tiež počas stretnutí v komunitnom centre. Ďalšiu skupinu tvoria tí, ktorí sa občas s Rómami stretnú ako bežní l’udia, alebo ako obchodník s kupujúcim, ktorý niečo potrebuje. Zistili sme, že je tu aj skupina duchovných, ktorí sa aj z rôznych osobných dôvodov vôbec nestretajú s Rómami, ktorých majú vo svojich farnostiach.

\section{- Ponuka sviatostného života}

Tab. 3 Pohl’ad duchovných na záujem Rómov o sviatosti

\begin{tabular}{|l|l|}
\hline Indukované kategórie & Aký majú vzt’ah k sviatostiam? \\
\hline Záujem & $\begin{array}{l}\text { "Je to výnimka, ale jedno diet’a má mimoriadny záujem o sviatosti. } \\
\text { Denne je na sv. omši." (RKC, 44). } \\
\text { "Mladá Rómka - stredoškoláčka - denne pristupuje k sviatostiam. } \\
\text { Stala sa aj animátorkou pre rómske deti.“(RKC, 28). } \\
\text { "Deti sa v našom centre s radostou pripravujú na 1. sv. prijímanie.“ } \\
\text { Rehol'ná sestra, 34. ročná. }\end{array}$ \\
\hline \multirow{2}{*}{ Zvyk } & $\begin{array}{l}\text { "S Rómami sa stretávam iba pri pohrebných obradoch. Viac odo mňa } \\
\text { ani nechcú." (RKC, 52). } \\
\text { "Moje aktivity s Rómami sú iba pri vysluhovaní krstu a pohrebe. } \\
\text { Nemajú záujem o nijakú prípravu k sviatostiam. “ (RKC, 48). }\end{array}$ \\
\hline Nezáujem & $\begin{array}{l}\text { "Zo strany Cirkvi je vel'ká ponuka, ale Rómovia o to nemajú záujem." } \\
\text { (RKC, 44). } \\
\text { „Nemajú vôbec záujem o sviatosti.“ (RKC, 45). }\end{array}$ \\
\hline
\end{tabular}

Identifikované kategórie: Spomínanou otázkou sme chceli zistit' vzt’ah a záujem Rómov o sviatosti, sviatostný život. Je tu skupina Rómov, zvlášt’ z mladšej generácie, ktorá má záujem o sviatosti, čo je ovocím pravidelného kontaktu s duchovnými nielen v škole, ale aj mimo školy. Najčastejšie sa naši participanti stretávajú so „zvykovost’ou“, a to hlavne pri pohrebných obradoch a občas aj pri vysluhovaní krstu. Tu sa potvrdzuje, že kontakt Rómov s Cirkvou je iba pri pohrebe, krste a nič viac, čo je smutné konštatovanie. Potvrdila sa nám aj skutočnost', ktorú väčšina l'udí v našej spoločnosti pokladá za pravdivú, že Rómovia nemajú záujem o sviatosti, aj ked' sa im ponúkajú. Pre nás je to však na zamyslenie. Prečo pretrváva takýto stav? Akým spôsobom a cestou im ponúkame sviatosti, ktoré by im vel'mi pomohli k sociálnej zmene? 


\section{- Pravidelnost' katechéz}

Tab. 4 Snaha o pravidelné aktivity duchovných s marginalizovanými Rómami

\begin{tabular}{|l|l|}
\hline Indukované kategórie & Ako často máte mimoškolskú katechézu? \\
\hline \multirow{2}{*}{ Pravidelne } & $\begin{array}{l}\text { „Detské sv. omše sú vel'kou príležitost'ou ako permanentne formovat' } \\
\text { mládež.“ (RKC, 28). } \\
\text { „Každú stredu sa stretávame v komunitnom centre na katechézach, } \\
\text { ktoré vel'mi pomáhajú Rómom.“ (RKC, 49). }\end{array}$ \\
\hline Občas & $\begin{array}{l}\text { „V mládežníckom spoločenstve sa venujeme všetkým. Mávame } \\
\text { občasnú katechézu, nerobíme rozdiely medzi rómskymi } \\
\text { a nerómskymi det'mi.“ (RKC, 44). } \\
\text { „Párkrát sme sa stretli, ale chýba pravidelnost' pri formácii s rodičmi.“ } \\
\text { (RKC, 30). }\end{array}$ \\
\hline Vôbec nie & "Nikdy." (RKC, 32). \\
\hline „Nemajú o to vôbec záujem.“ (RKC, 52).
\end{tabular}

Identifikované kategórie: Pravidelná mimoškolská katechéza je pre duchovných často namáhavá, čo by aj oni sami potvrdili, ale má zmysel ju realizovat'. Potvrdili nám to aj odpovede našich respondentov, ktorí pravidelne konajú katechézy, pri ktorých vysvetl'ujú rôzne náboženské pravdy, ale hlavne formujú svedomie Rómov, čo im pomáha k sociálnej zmene. Vel'kou pomoc, hlavne pre mladých, sú rôzne mládežníčke spoločenstvá. Nie sú to už skupiny homogénne, ale heterogénne, čo účinne pomáha vzájomným vzt'ahom, budovaniu úcty, rešpektovaniu odlišností, ale hlavne $\mathrm{k}$ budovaniu mostov medzi Rómami a majoritou. Objavili sa aj prípady duchovných, ktorí nerobia žiadnu katechézu. $Z$ akých dôvodov, to by bolo možné zistit' pri d’alšom výskume. Môže to byt' aj výsledok jednostranného alebo obojstranného nezáujmu.

\section{- Najúčinnejšie pastoračné aktivity}

Tab. 5 Najúčinnejšie pastoračné aktivity podl'a duchovných

\begin{tabular}{|l|l|}
\hline Indukované kategórie & Čo sa oplatí robit’? \\
\hline Osobný kontakt & $\begin{array}{l}\text { Osobný kontakt je vel'ká pomoc ako sa k ním dostat' a postupne ich } \\
\text { formovat', aby si aj oni sami uvedomili, v čom sa majú osobne zmenit', } \\
\text { aby ich život bol lepší, aby pohl'ad majority nebol iba negatívny.“ } \\
\text { (RKC, 49). } \\
\text { „Pastoračná činnost' je u nás hlavne zameraná na duchovnú pomoc cez } \\
\text { osobné rozhovory, modlitby a všetko, čo k tomu patrí.“ Apoštolská } \\
\text { cirkev, 45. ročný. }\end{array}$ \\
\hline Farská aktivita & $\begin{array}{l}\text { „Rómski aj nerómski rodičia chodia s det'mi pred 1. sv. prijímaním do } \\
\text { farského centra na pravidelné katechézy.“ (RKC, 49). } \\
\text { „Farské letné tábory pomohli mnohým rómskym det'om začat' } \\
\text { pravidelne pristupovat' k sviatostiam a dvaja chlapci z nich denne } \\
\text { miništrujú.“ (RKC, 28). }\end{array}$ \\
\hline
\end{tabular}




\begin{tabular}{|l|l|}
\hline \multirow{5}{*}{ Rodina } & $\begin{array}{l}\text { "Najefektívnejšia aktivita, ktorá vedie k sociálnej zmene, je v spôsobe } \\
\text { priblíženia sa - návšteva rodín. Rómovia si vel'mi vážia, ked' ich } \\
\text { Neróm navštívi so záujmom o jeho životné problémy.“ Náboženská } \\
\text { spoločnost' Jehovovi svedkovia, 27. ročný. }\end{array}$ \\
& "Snažím sa vstúpit' do rómskej rodiny, spoznat' ich životné problémy, \\
nenútit' ich chodit” do kostola. Jednoducho povedané, byt' s nimi \\
priatel'." (RKC, 49). \\
"Návšteva rómskej rodiny obohacuje aj mňa. Spoznávam dimenzie \\
života, rodiny, ktoré boli pre mňa neznáme.“ (RKC, 52).
\end{tabular}

Identifikované kategórie: Získane údaje môžu odzrkadl'ovat' aj subjektívne vnímanie duchovných pri hodnotení ich najúčinnejších pastoračných aktivít. Jednoducho povedané, čo sa oplatí robit', aby sa naozaj dosiahla sociálna zmena u l'udí, ktorým sa venujú. Osobný kontakt s Rómami považujú za vel'kú pomoc, most, aby sa spoznali, aby si vybudovali vzájomnú dôveru, ale hlavne aby Rómovia pochopili, že im chcú duchovní pomôct’ k lepšiemu životu tu na Zemi a k večnému št'astiu po smrti. Ani farské aktivity už nie sú zriedkavost’ou. Sú tiež pomocou pre vzájomné zblíženie sa a formáciu, čo prináša svoje ovocie v sociálnej zmene a v miere zapojenia sa do farského života s majoritou. Niektorí respondenti pokladajú vstup do rodiny za najefektívnejšiu aktivitu. Vidia v nej nielen nábor pre chodenie do kostola, ale vel'kú šancu spoznat' rómsky svet, poznat' prostredie, od ktorého sa všetko odvíja v živote Róma. Zistili sme, že vstup do rodiny nie je prínosom len pre Rómov, ale aj pre samotných duchovných, ktorí poznávajú ich svet, hodnoty a kultúru, čo im pomáha pri pastorácii, ktorá vedie niektorých Rómov k sociálne zmene.

\section{DISKUSIA}

V súčasnosti sú duchovní všetkých cirkví vel'mi povzbudzovaní slovami i príkladom pápeža Františka. Pápež chce, aby Cirkev bola služobníčkou pre všetkých l'udí, aby bola „Cirkvou vychádzajúcou“ k najslabším, najzranitel’nejším, marginalizovaným, a aby sa ich ujala s krehkost’ou a bola im nablízku. Nechce, aby sme boli l’ahostajní voči biedam sveta, ale kráčali spolu s l'ud'mi, ktorí sú zranení rôznym spôsobom (František, 2013). Mnohí duchovní sa snažia vo svojich pastoračných aktivitách naozaj byt' nablízku v biedach l'udí, všestranne im pomáhajú, a tak ich privádzajú k osobnej konverzii, ktorá ako sprievodný jav prináša ich sociálnu zmenu. Niektorí duchovní sa prebúdzajú, začínajú lepšie vnímat’ aj potreby mnohých Rómov, ktorí sa dostali do zlej sociálnej situácie. Uvedomujú si, že nemôžu byt' zatvorení v kostole, na fare, nemôžu byt' izolovaní od l'udí, ale musia íst' ku nim. To ich poháňa, aby vychádzali zo seba k potrebám druhých. Svoje pastoračné aktivity realizujú tímovo, aby čo najlepšie pohli k sociálnej zmene osoby, ktorým sa venujú. Tak, ako celá naša spoločnost' vidí rozpad rodiny, aj oni si uvedomujú nevyhnutnost' posilňovat' rómsku rodinu a pomáhat' jej, aby sa nerozpadla, ale aby bola stabilná a funkčná. Vedia, že nefunkčnost' rodiny je zárodkom pre všetky sociálne problémy. Preto sa snažia vstúpit’ aj do rómskej rodiny, aby ju posilnili, chránili, a tak zamedzili zlu, ktoré sa potom z nich dostáva do celej spoločnosti. V rodine, kde už nastali rôzne sociálne problémy sa snažia zachránit', čo sa dá, ale hlavne vedú jednotlivcov, aby sa postavili na vlastné nohy, neboli iba tlačení, ale prevzali svoj život do vlastných rúk. Táto ich zodpovednost' je tiež ovocím ich sociálnej zmeny. Aby sme boli objektívni, musíme spomenút', že v našom výskume sa objavili aj duchovní, ktorí z rôznych dôvodov nerealizovali pastoračné aktivity a nejavili záujem o to, aby pomohli osobám, ktoré sa nachádzajú v zlej sociálnej situácii.

Opisovat' a hodnotit' prácu s l'ud'mi nie je také jednoduché. Sú to dimenzie často nemeratel'né. Výsledky, na ktoré čaká každý výskumník sú od neho míle vzdialené. Výskum, ale hlavne práca s niektorými skupinami Rómov, ktorým by sme chceli pomôct', s ktorými sa denne stretávame, 
o ktorých často počujeme z rôznych médií iba negatívne skutočnosti, je beh na dlhú trat'. Aj náš výskum má svoje limity. Mohli sme oslovit' viacerých duchovných, ktorí majú vo svojich farnostiach Rómov. Bolo by vel'mi užitočné, keby sme našich respondentov viac povzbudili do pastoračnej aktivity, ponúkli im pomoc, zoznámili ich s duchovnými, ktorým sa podarilo priviest' niektorých Rómov k sociálnej zmene. V našom výskume nám niekedy chýbala odvaha. Dali sme sa odradit' nezáujmom niektorých duchovných, ktorí vôbec nereagovali na náš elektronický dotazník ani na ponuku osobného stretnutia. Radi by sme povzbudili tých, ktorí chcú robit' výskum v podobnej oblasti, aby ho realizovali radšej ako tím a nedali sa odradit' prípadným nezáujmom opýtaných respondentov. Je dôležité, aby mali vždy pred sebou ciel', že chcú pomôct’ a nájst' spôsob, ako riešit’ problémy, do ktorých sa dostávajú hlavne niektoré skupiny Rómov žijúce v nepriaznivej sociálnej situácii.

Náš krátky príspevok nechce byt' kritikou, ale hlavne povzbudením. Oplatí sa investovat' do pastoračnej činnosti, ktorá má pomôct’ k sociálnej zmene niektorých skupín Rómov, ktorí sa ocitli v prostredí marginalizácie a nemajú síl ani prostriedkov, aby sa vymanili zo začarovaného kruhu, v ktorom sa každým dňom ponárajú hlbšie nielen do hmotnej biedy, ale aj do tej duchovnej.

Odporučili by sme formátorom duchovných, aby pomohli hlavne mladej generácii dobre sa pripravit' na pastoráciu, na život v terénne, tak ako nám to v poslednej dobe vel'mi často pripomína pápež František. Jeho prianím je pastoračná konverzia v misionárskom zmysle. Dôležité je, aby sme pochopili, že je potrebná nová evanjelizácia, pretože sa už nemôžeme viac domnievat', že väčšina l'udí sú veriaci, a že porozumeli tomu, v čom spočíva krest’anské posolstvo $\mathrm{v}$ jeho podstate a v jeho pravde. Preto je dôležité, aby sme si z našej strany osvojili podstatu a srdce Evanjelia a predložili ho jazykom, ktorý bude zrozumitel'ný l'ud'om našej doby, takými prostriedkami, ktoré sa naozaj dostanú až k adresátom a v našom prípade aj k Rómom. Je tu čas každodennej pokornej misie, sprevádzania l'udí s úctou a nehou, osobitne tých najnúdznejších. Duchovných by sme povzbudili, aby boli blížnymi tomu, kto to najviac potrebuje, koho „kultúra vyradenia" odsúdila a je l'ahostajná k jeho potrebám. $Z$ nášho výskumu by sme mohli len potvrdit', že často sú to aj niektorí Rómovia, ktorí sa dostali do zlej sociálnej situácie. Majme odvahu priznat'si, že problém nie je iba v Rómoch. Vnašom výskume sme zistili, že aj v niektorých duchovných. Efektivita pastorácie nespočíva iba v tom, že sa s Rómami stretneme iba pri vysluhovaní krstu a pohrebu. Je nutné mat' odvahu urobit' aj kroky navyše, kroky ktoré nám pomôžu zbližit' sa s nimi, spoznat' ich skutočné potreby a pomôct' im v čom sa dá. Vel'ká pomoc na tejto ceste, podl'a nášho výskumu, je vstup do rodiny, práca v tíme a permanentnost'.

Pre tých, ktorým sa zdá, že sú neúspešní vo svojej pastoračnej činnosti aj napriek mnohým snahám, ktoré vynaložili na pomoc Rómom by sme odporučili, aby sa neznechucovali a mali odvahu znovu začat'. Ako? Začat' evanjelizáciou a skutočným obrátením rómskych sŕdc. Bez osobného obrátenia je sociálna práca mnohokrát odsúdená na neúspech a mnohé materiálne prostriedky, peniaze, ktoré sa investujú do sociálnej oblasti sa len prepadnú ako do vreca, ktoré nemá dna.

Pre všetkých čitatel'ov by sme chceli zanechat' odkaz Benedikta XVI. (2007), že miera l'udskosti je podstatne určovaná vzt’ahom $k$ utrpeniu a k trpiacim. Platí to pre jednotlivcov i pre spoločnost'. Prijat' trpiaceho blížneho, pomôct' $k$ sociálnej zmene niektorým Rómom totiž znamená vziat' určitým spôsobom na seba jeho utrpenie, ktoré sa stane aj mojím. Nie je to l'ahká úloha, ale je to štýl života, ktorým sa postavíme proti prevládajúcej kultúre vyrad'ovania, proti l'ahostajnosti, ktorá zaplavuje svet ako mor a staneme sa tak propagátormi novej civilizácie, civilizácie lásky.

\section{LITERATÚRA}


Adami, P., \& Martír, R. (2014). Pastorácia. In Medzinárodná konferencia CCIT v Cavallino. Taliansko.

Analýza, (2014). [On-line publication] [vid. 2016-01-06]. Dostupné z: <http://www.fluidumfilm.sk/vyvoj/luskanie/>

Benedikt XVI. (2008). Spe salvi, Encyklika. Trnava: SSV.

Bešenyei, P. (2011). Opatrenia a ponuky katolíckej misie v procese socializácie rómskeho etnika na Slovensku, Dizertačná práca. Bratislava: VŠZ a SP sv. Alžbety v Bratislave.

František (2013). Evangelii gaudium. Trnava: SSV.

Giovanni XXIII. (2007). Tutti i principali documenti. Vatican: Liberia Editrice.

Holmen, M. (2014). Viera sa začína doma. Bratislava: Don Bosco.

Svoboda, J. (2009). Predstavenie práce v Bulharsku. In P. Bešenyi (Ed.), Preventívny systém $v$ rómskom svete. Medzinárodná konferencia o pastorácii Rómov 20. - 23. novembra 2009 (s. 50 56). Košice.

Kuchař, P. (2009). Romové v České republice. In P. Bešenyi (Ed.), Preventívny systém v rómskom svete. Medzinárodná konferencia o pastorácii Rómov 20. - 23. novembra 2009 (s. 63-72). Košice.

Košta, J. (1993). Úvod do sociológie. Bratislava - Ekonomická univerzita.

Lucian, T. (2015). Život chudobných. Medzinárodná konferencia CCIT v Snagov, Rumunsko, 25.4. 2015.

Miedzgová, J. (1994). Základy etiky. Bratislava: SPN.

Miovsky, M. (2006). Kvalitativní př́stup a metody v psychologickém výzkumu. Praha: Grada Publishing.

Montoussé, M., \& Renouard, G. (2005). Přehled sociologie. Praha: Portál.

Podolínska, T., \& Hruštič, T. (2010). Boh medzi bariérami. Sociálna inklúzia Rómov náboženskou cestou. Bratislava: ÚET SAV.

Rómske rodiny, (2015). Nevy Jag - Anketa v Mad'arsku. Merksem. 28 s.

Sopóci, J. (2007). Teórie sociálnej zmeny. Bratislava: UK.

Veraga, P. (2009). Predstavenie práce salezianov v La Mina, Španielsko. In P. Bešenyi (Ed.), Preventívny systém v rómskom svete. Medzinárodná konferencia o pastorácii Rómov 20. - 23. novembra 2009 (s. 81-87). Košice.

Abstract:

Pastoral Activities and Social Change in Roma People

Background: Multiple home and foreign experiences prove the fact that thorough pastoral activities with poor Roma are able to trigger a reaction in a form of a social change.

Objective: The objective was to map the most efficient methods of pastoral activities that are able to trigger a social change, and to find out what results are brought by pastoral activities in some groups of Roma in a difficult social situation.

Methods: By the method of a semi-structured interview with 27 clergymen from the registered churches in the SR active in the Diocese of Nitra we analysed the results by the method of forming tufts. A sampling criterion included the previously searched information about pastoral activities of the clergymen.

Results: The results show that the clergymen in their activities work particularly with children and youth, even though they admit that if there is to be a change it is necessary to work with the children's parents. In most cases, they meet poor Roma only at school, or occasionally in a municipality. They admit that Roma are interested in the sacraments - particularly christening and funeral; however, it is too little for the churches. With the children, they organize a regular out-of-school catechesis and establish youth communities. However, 
we identified the cases of the clergymen who do no activities related to Roma. Those who do such activities consider particularly a personal contact, which is a bridge to other activities, the most efficient method of work. Implications: The clergymen of all churches should be servants of all people. If we want to achieve a social change in the marginalized groups of population it is necessary for clergymen to come out of their zone of conformity and be closer to vulnerable people. Working with youth but particularly with whole families can result in big changes. Such work, however, must be regular, and particularly personal contacts in the field is the basis of a future change. Occasional contacts solely in the church or parsonage are not efficient.

Keywords: Pastoral activity. Roma. Social change. 